PEMBELAJAR: Jurnal Ilmu Pendidikan, Keguruan, dan Pembelajaran

Volume 2 Nomor 2 Oktober 2018 Hal. 132-137

e-ISSN: 2549-9114 dan p-ISSN: 2549-9203

(Received: Agustus-2018; Reviewed: September-2018; Published: Oktober 2018)

DOI: http://dx.doi.org/10.26858/pembelajar.v2i2.7164

\title{
Gangguan Emosional Anak Akibat Tayangan Misteri Televisi (Studi Kasus Pada Anak Usia 2-11 Tahun)
}

\author{
Musfira \\ Universitas Muhammadiyah Makassar \\ Corresponding e-mail: Musfiramansyur28@gmail.com
}

\begin{abstract}
Abstrak: Penelitian bertujuan untuk (1) mengetahui identifikasi gangguan emosi yang dialami oleh anak usia 2-7 tahun karena sering menyaksikan tayangan misteri di televisi, (2) mengetahui identifikasi gangguan emosi yang dialami oleh anak usia 7-11 tahun karena sering menyaksikan tayangan misteri di televisi. Jenis penelitian ini adalah penelitian kualitatif dengan dengan metode studi kasus dengan subjek penelitian sebanyak tiga orang anak dengan klasifikasi umur yang berbeda. Dua anak dari fase pra operational dan seorang anak dari fase operationait. Teknik pengumpulan data yang digunakan dalam penelitian ini adalah observasi, wawancara dan dokumentasi. Hasil penelitian memberikan kesimpulan bahwa gangguan emosi yang dialami oleh anak dari kelompok pra operational (2-7 tahun) adalah cengeng, sering mengigau, penakut, dan selalu merasa dibayang-bayangi sehingga mempengaruhi fisiknya dengan dada yang berdebar-debar, gemetar, dan berkeringat dingin. Sedangkan anak dari kelompok operational konkrit (7-11) tahun mengalami rasa takut yang berlebihan, tidak mandiri dan takut terhadap binatang-binatang tertentu bahkan rasa takut yang selalu menghantuinya terkadang mempengaruhi stamina tubuhnya sehingga rentan terhadap penyakit. Gangguan emosi yang dialami oleh masing-masing anak tergantung pada intensitas anak dalam menonton tayangan misteri dan kadar mistik yang terkandung dari tayangan tersebut
\end{abstract}

Kata Kunci: Gangguan emosional anak, Tayangan Misteri Televisi

\begin{abstract}
This study aims to: (1) understand the emotional disturbance experienced by children aged 2-10 years old because they often watch a mystery program an television, (2) understand the physical problems experienced by children aged 2-10 years old as a result of emotional disturbance because the frequently watch mystery television program.This research is a qualitative research with case study method with three children with different age classifications as research subject. Two children are from pre-operational phase and a child from the concrete operational phase. The data collection techniques used in this research are observation, interview and documentation. The results provide conclusion that the emotional distress experienced by children (2-10 years old) is whyny, often delirious, coward and always felt overshadowed, not independent, and fear of certain animals and thus affects his physical with the chest thumping, trembling and cold sweat and stamina of his body became weak, so vulnerable to disease. Emotional disturbances experienced by each child depend on the intensity of children watching mystery program in the mystique level contained in those program
\end{abstract}

Keywords: Emotional Disordes of Children; Mystery Television Program

○2018 -Pembelajar Universitas Negeri Makassar. Ini adalah artikel dengan akses terbuka dibawah licenci CC BY-NC-4.0 (https://creativecommons.org/licenses/by-nc/4.0/ ).

\section{PENDAHULUAN}

Televisi merupakan salah satu media yang mudah dan murah diperoleh masyarakat.
Kemampuan televisi menampilkan audio (suara) dan visual (gambar) secara bersamaan menyebabkan televisi memiliki banyak penonton. Selain itu media televisi tidak 
mengenal batas usia, jenis kelamin, maupun status sosial seseorang, sehingga anak usia dini menjadi pemirsa yang paling rentan untuk menikmatinya. Saat ini televisi merupakan sarana yang paling digemari dan dicari orang, karena mampu menyebarkan informasi dalam jumlah yang tak terhingga dan pada waktu yang bersamaan. Untuk mendapatkan televisi tidak lagi sesulit zaman dulu dimana media elektronik ini adalah barang langka yang hanya dapat dimilki oleh kalangan tertentu. Kini, hampir seluruh keluarga memilki perangkat komunikasi tersebut dan telah menjangkau lebih dari $90 \%$ penduduk di negara berkembang. (http. Ariperon.wordpress.com, 6 Januari 2009)

Ari Setyaningsih dalam blognya memaparkan bahwa Dwyer menyimpulkan TV mampu merebut 94\% saluran masuknya pesan - pesan atau informasi ke dalam jiwa manusia yaitu lewat mata dan telinga. TV mampu untuk membuat orang pada umumnya mengingat 50\% dari apa yang mereka lihat dan dengar dilayar televisi walaupun hanya sekali ditayangkan. Atau secara umum orang akan ingat $85 \%$ dari apa yang mereka lihat di TV setelah 3 jam kemudian dan $65 \%$ setelah 3 hari kemudian. Dengan demikian, anak-anak yang pada umumnya selalu meniru apa yang mereka lihat, tidak menutup kemungkinan perilaku dan sikap anak tesebut akan mengikuti acara televisi yang ia tonton. Apabila yang ia tonton merupakan acara yang lebih kepada edukatif, maka akan bisa memberikan dampak positif tetapi jika yang ia tonton lebih kepada hal yang tidak memiliki arti bahkan yang mengandung unsur-unsur negatif atau penyimpangan bahkan sampai kepada kekerasan, maka hal ini akan memberikan dampak yang negatif pula terhadap perilaku anak yang menonton acara televisi tersebut.

Dewasa ini, penyelenggara siaran televisi semakin bertambah. Beberapa tahun yang lalu hak penyiaran televisi dimonopoli oleh pemerintah, namun saat ini hak penyiaran dapat dilakukan oleh siapa saja yang memiliki modal. . Sejak tahun 1989 TVRI mendapatkan saingan siaran televisi lainnya, yakni Rajawali Citra Televisi Indonesia (RCTI) dan secara berturut-turut berdiri stasiun televisi lainnya yaitu Surya Citra Televisi (SCTV), Televisi Pendidikan Indonesia (TPI), Andalas Televisi (ANTV), Indosiar, TV7, Lativi, Metro TV, JakTV, Bali TV, dan lain-lain. (Sumita Tobing : 2001). Hal ini memudahkan untuk memindahkan saluran televisi dari satu saluran ke saluran yang lain dan akibatnya alokasi waktu yang digunakan anak-anak untuk menonton siaran televisi semakin bertambah.
Televisi sebagai salah satu media yang handal dalam menyampaikan informasi memiliki andil dalam memajukan pengetahuan masyarakat, terbukti dengan semakin beraneka ragamnya program yang ditampilkan, ada siaran berita aktual, olah raga, musik, kerohanian, dan lain-lain, kontribusinya terhadap kemorosotan nilai-nilai kehiodupan tidak bisa diabaikan. Media yang seharusnya menjadi sarana informasi bagi masyarakat untuk menambah pengetahuan mereka baik di luar mau pun didalam, justru sebaliknya. Televisi sebagai media terkadang mengabaikan peraturan yang berlaku dalam menyiarkan program-programnya, terutama anjuran yang dikeluarkan oleh Komisi Penyiaran Indonesia. Hal ini disebabkan karena media hanya mencari keuntungan semata, sehingga media tidak memperdulikan lagi apakah program-program tersebut terutama yang berisi kandungan kekerasan, seks dan misteri akan berdampak buruk atau baik bagi para konsumennya. (Wuryanta, 2006, Perilaku anti sosial : Tayangan Misteri, Seks dan Kekerasan)

Implikasi negatif inilah yang terkadang luput dari pantauan kita, khususnya bagi orangtua. Kita lebih mengedepankan prasangka-prasangka positifnya terhadap beberapa suguhan program televisi sehingga membiarkan anak-anak bebas tanpa kontrol dalam menontonnya. Padahal kalau kita amati secara lebih serius, banyak dari program televisi yang kurang mendidik atau bahkan memberi efek negatif terhadap perkembangan mental dan moral anak.

Seperti pernyataan Komisionir Komisi Penyiaran Indonesia (KPI) Don Basco Selamun bahwa hampir semua tayangan anak melanggar Pedoman Prilaku Penyiaran dan Standard Program Siaran P3-SPS. Bagi beliau tayangan televisi saat ini dianggap melanggar karena mengandung unsur kekerasan, mistik, pornografi, dan memberi contoh buruk pada perkembangan mental anak (Kompas, 4/5/08).

Salah satu siaran televisi yang digemari oleh penonton adalah tayangan -tayangan misteri. Sebuah tayangan yang menyiarkan hal-hal yang menyangkut dunia mistis seperti setan, makhluk gaib lainnya, arwah gentayangan, benda-benda keramat dan sebagainya (Surbakti:2008). Tayangan mistik atau tayangan tahayul adalah jenis tayangan visual berupa informasi pemberitaan , acara rekayasa realita ataupun produksi cerita fiksi mistik berbasis tradisi masyarakat melalui media massa TV atau film

Menurut Surbakti (2008) dampak buruk dari tayangan misteri televisi terhadap psikis anak - 
anak adalah terganggunya perkembangan emosi mereka. Gangguan emosi mereka direalisasikan dalam bentuk ketakutan, seperti takut tidur sendiri, tidak berani ke kamar mandi, merasa dibayang-bayangi dirinya, tidak berani berada dalam rumah seorang diri apalagi sampai mengalami mimpi buruk. Selain itu tayangan misteri televisi menimbulkan gangguan fisik anak . gangguan fisik yang paling sering terjadi adalah : mengompol di tempat tidur, konsentrasi belajar terganggu, mengalami kesulitan belajar, lesu dan tidak bertenaga, sulit makan, pencernaan terganggu, sakit perut bahkan kadang-kadang disertai diare.

Euis dalam artikelnya mengatakan bahwa anak usia dini yang berulang kali menonton tayangan mistis akan berpengaruh pada kepribadiannya. Anak akan tumbuh menjadi orang yang selalu ketakutan dan kelak ketika dewasa ia akan mengambil keputusan hanya mengandalkan emosinya saja karena tayangan tersebut menyebabkan neokorteks dalam otak anak menjadi tumpul. Selain itu, membiasakan anak untuk menonton televisi akan mengurangi kemampuannya untuk mengemukakan pendapatnya secara logis dan sensitif, karena kerja syaraf motorik dan sensoriknya kurang terangsang. Hal ini akan mengurangi kemampuan anak untuk meningkatkan kemampuan fisik, berbahasa dan berinteraksi dengan lingkungan sosialnya (http.www.pksjaksel.or.id/article939.htm).

Anak 12 Tahun bernama Heri Setiawan, meninggal dunia setelah ditemukan tergantung di ranjang tingkat. Peristiwa meninggalnya Heri Setiawan ini diduga tewas karena keingintahuannya mempraktikkan trik sulap dari Limbad, ( tayangan Master of Limbad) tokoh favoritnya di televisi. Pengakuan keluarga, Heri tidak pernah melewatkan acara sulap dan selalu menirukan atraksi sulap The Master Limbad. walaupun Limbad menyangkal atraksinya yang disiarkan stasiun RCTI merupakan penyebab dari kematian Heri namun pengakuan keluarganya menguatkan penyebab dari kematian anak tersebut.(www. Oktavita.com.19 Desember 2009)

Kenyataan di lapangan yang diamati oleh penulis menunjukkan bahwa terdapat seorang anak berusia 3 tahun yang selalu ketakutan jika telah menyaksikan tayangan-tayangan misteri di televisi. Menurut pengakuan ibunya yang gemar menyaksikan tayangan-tayangan misteri televisi, bahwa anaknya seringkali ikut nonton bersamanya tetapi setelah itu dia biasa mengigau bahkan menjerit-jerit di malam hari.
Kasus lain adalah seorang anak yang berumur 5 tahun, berdasarkan informasi dari ibunya (16 Februari 2010) mengalami ketakutan untuk tidur sendiri dan merasa selalu ada yang membayang-bayangi dirinya setelah beberapa kali menyaksikan tayangan film horor di televisi.

Berdasarkan fakta di atas menunjukkan bahwa anak-anak akan mengalami gangguan emosi karena sering menyaksikan tayangantayangan misteri yang disiarkan oleh televisi, maka penulis tertarik untuk mengkaji identifikasi gangguan emosional yang dialami anak-anak (211 tahun) sebagai akibat dari kebiasaan mereka menonton tayangan-tayangan misteri di televisi.

\section{METODE}

Penelitian ini mengumpulkan data tentang perilaku anak yang mengalami gangguan emosi karena sering menyaksikan tayangan misteri televisi melalui:

a. Observasi, merupakan teknik pengumpulan data dengan mengamati secara langsung sasaran (subyek) penelitian dengan merekam peristiwa dan perilaku secara wajar. Dalam pengamatan ini peneliti hanya sebagai pengamat partisipatif yang pasif artinya peneliti mengamati tapi tidak terlibat dalam kegiatan tersebut.

b. Wawancara, dilakukan dengan menggunakan pedoman wawancara. Peneliti akan menyusun pokok-pokok permasalahan yang akan ditanyakan dalam proses wawancara untuk memperoleh data tentang perilaku anak yang menunjukkan gangguan emosi akibat tayangan misteri yang sering mereka tonton.

c. Dokumentasi, yaitu data yang relevan dengan fokus penelitian berupa dokumen perkembangan anak, data tentang keluarga, dan catatan anekdot.

Langkah-langkah konkrit dalam menggali data adalah :

a. Mengidentifikasi gangguan emosi yang dialami oleh anak yang berusia 2-7 tahun setelah menyaksikan tayangan misteri televisi

b. Mengidentifikasi gangguan emosi yang dialami oleh anak yang berusia 7-11 tahun setelah menyaksikan tayangan-tayangan misteri di televisi

c. Menginterpretasi intensitas kebiasaan anak usia dini menyaksikan tayangan misteri televisi 
d. Mendeskripsikan jenis-jenis tayangan misteri televisi yang menyebabkan gangguan emosi pada anak usia dini

\subsection{Sumber data}

Informan yang menjadi sumber data dalam penelitian ini adalah :

a. tiga orang anak yang sering menyaksikan tayangan misteri televisi dari kelompok umur 2-7 tahun dan yang berumur 7-11 tahun

b. orang tua dari masing-masing anak

c. anggota keluarga lain dari anak yang diteliti

Sumber data lain yang akan melengkapi penelitian ini adalah data yang diperoleh dari buku-buku, artikel, journal, internet, pendapat para ahli yang berkaitan dengan objek penelitian maupun peraturan perundang-undangan yang berlaku saat ini.

Data yang terkumpul dalam penelitian ini dianalisis dalam kegiatan yang meliputi reduksi data, penyajian data, penarikan kesimpulan dan melaksanakan verifikasi. Data yang terkumpul merupakan hasil wawancara dan pengamatan yang akan dilakukan oleh peneliti dalam keluarga anak yang bersangkutan. Langkah-langkah yang dilakukan dalam menganalisis data adalah sebagai berikut :

a. Reduksi data maksudnya merangkum data yang sesuai dengan masalah penelitian. Data yang tidak sesuai dengan masalah penelitian dipisahkan dan hanya akan digunakan jika memang kemudian dibutuhkan oleh peneliti.

b. Penyajian data. Data hasil wawancara dan observasi akan disajikan dalam bentuk tabel yang diurutkan berdasarkan tanggal pelaksanaannya dan memberikan kode pada hasil wawancara sesuai dengan masalah penelitian.

c. Penarikan kesimpulan. Setelah semua data hasil wawancara dan observasi terkumpul lalu disusun untuk mengambil suatu kesimpulan.

d. Untuk menguji keabsahan data yang telah diperoleh maka peneliti akan melakukan triangulasi metode dan sumber sehingga data yang diperoleh memiliki tingkat kepercayaan yang berkaitan dengan kebenaran hasil penelitian.

e. Triangulasi metode akan dilakukan dengan cara membandingkan hasil penelitian yang diperoleh melalui wawancara dan observasi. Pengamatan yang akan dilakukan pada subjek dilakukan sealami mungkin sehingga subjek tidak menyadari bahwa peneliti sedang melakukan proses pengamatan. Hasil pengamatan yang mendukung hasil wawancara menunjukkan tingkat kebenaran informasi yang diberikan oleh subjek. Apabila hasil pengamatan dan wawancara tidak sesuai maka peneliti mencoba mencari data melalui pengamatan dan wawancara berikutnya.

f. Triangulasi sumber akan didilakukan dengan cara melakukan wawancara terhadap anggota keluarga dan orang lain yang tidak memiliki hubungan keluarga namun dekat dengan kehidupan anak yang akan diteliti, misalnya orang tua, kakak, adik, pembantu, guru, tetangga maupun teman-teman subjek.

g. Hasil wawancara dengan sumber-sumber penelitian akan dibandingkan dengan hasil wawancara dengan subjek jika data yang diperoleh saling mendukung maka data tersebut memiliki tingkat kepercayaan dengan tingkat kebenaran kesimpulan akhir hasil penelitian dapat dipertanggungjawabkan

\section{HASIL DAN PEMBAHASAN}

Berdasarkan data-data yang telah peneliti dapatkan di lapangan maka hasil penelitian yang diperoleh adalah sebagai berikut :

a. Jenis tayangan misteri televisi yang sering disaksikan oleh subjek adalah:

1) Upin Ipin di TPI

2) Kisah Fantasi di TPI

3) Film Bioskop Indonesia di Trans TV

4) Plesetan Misteri di Trans 7

5) The Master di RCTI

6) Raja Sulap di Indosiar

7) Ronaldowati di TPI

8) Scary Job di Trans 7

9) Realigi di Trans TV

10) Sketsa di Trans TV

11) Keluarga Hantu di Trans 7

b. Kadar mistik yang terkandung dalam tayangan misteri yang disiarkan oleh televisi ada dua macam yaitu :

1) Tayangan yang kadar mistiknya berat

2) Tayangan yang kadar mistiknya ringan

c. Frekuensi subjek dalam menyaksikan tayangan misteri di televisi adalah :

1) satu kali

2) Lebih dari satu kali (sering)

d. Reaksi subjek setelah menyaksikan tayangan misteri adalah digolongkan ke dalam 2 bagian yaitu :

1) reaksi yang akan segera muncul (pada saat menyaksikan) maka subjek mengalami : 
a) menjerit-jerit

b) menangis

c) menutup matanya dengan bantal

d) sembunyi

e) gemetar

f) jantung berdebar-debar

2) reaksi yang akan muncul (panjang) subjek terhadap tayangan misteri televisi adalah :
a) takut
b) merasa dibayang-bayangi
c) bergantung (tidak mandiri)
d) phobia pada binatang-binatang tertentu

\section{KESIMPULAN DAN SARAN}

Hasil penelitian ini memberikan gambaran tentang ciri-ciri gangguan emosi yang dialami oleh anak dengan rentang usia antara 2 sampai dengan 10 tahun akibat tayangan misteri televisi. Gangguan emosi yang dialami masing-masing anak berbeda sesuai dengan tingkatan umur, frekuensi dan kadar mistik dari jenis tayangan misteri yang telah disaksikan subjek. Berdasarkan hasil penelitian dan pembahasan, maka kesimpulan yang diperoleh dalam penelitian ini adalah: Gambaran pelaksanaan evaluasi dalam rangka mengetahui perkembangan bahasa anak yang diterapkan di lapangan tidak sesuai dengan harapan, guru terkadang tidak melakukan evaluasi khususnya pada perkembangan bahasa anak dan anak kurang terlibat aktif dalam pembelajaran. Berdasarkan permasalahan yang ada, maka dianggap perlu untuk merancang sebuah perangkat evaluasi perkembangan bahasa anak usia dini.

a. Subjek I (laki-laki) yang berumur 2 tahun lima bulan telah beberapa kali menyaksikan tayangan misteri di televisi melalui tontonannya sendiri dan tontonan ibunya yang menjadi konsumsi orang dewasa. Subjek I dibiasakan untuk menyaksikan siaran televisi agar beban ibu untuk mengasuh subjek lebih ringan.

b. Tayangan misteri yang telah disaksikan oleh subjek I melalui tontonannya sendiri berupa serial khusus untuk anak-anak dalam serial Upin- Ipin dan sinema yang ada dalam kisah Fantasi. Kadar mistik dari tayangan tersebut tergolong ringan. Sedangkan tayangan yang berasal dari tontonan ibunya adalah berupa film layar lebar atau sinema horor yang di programkan masing-masing stasiun televisi, dengan kadar mistik yang berat c. Dampak dari tayangan misteri yang telah disaksikan subjek menimbulkan reaksi langsung dengan bahasa tubuh yang menunjukkan rasa takut yang diekspresikan dengan cara menjerit hingga menangis. Sedangkan dampak berupa reaksi panjang yang dialami subjek adalah mengigau (mimpi buruk).

d. Subjek 2 (perempuan) yang berumiur 6 tahun sering menyaksikan tayangan misteri di televisi karena mengikuti tontonan kakaknya. Kesibukan orang tua mengharuskan subjek untuk selalu berada di bawah pengawasan kakaknya, oleh karena itu subjek harus mengikuti selera nonton kakaknya yang kebetulan menyukai tayangan misteri.

e. Tayangan misteri televisi yang telah disaksikan subjek lebih variatif jika dibandingkan dengan yang telah disaksikan oleh subjek 1, mulai dari tayangan mistik yang kadar misterinya ringan berupa tayangan mistik fiksi komedi hingga yang berat berupa tayangan mistik horror.

f. Reaksi subjek 2 saat sedang menyaksikan tayangan misteri di televisi tergantung dari kadar mistik yang dimiliki tayangan tersebut. Rasa takut disertai dengan reaksi fisik berupa dada yang berdebar-debar, gemetar dan merinding. Sedangkan reaksi panjang terhadap subjek mengakibatkan subjek menjadi penakut dan perasaan selalu dibayang-bayangi oleh hantu yang pernah disaksikan di televisi. Reaksi fisiknya adalah mengulangi kebiasaan buruknya yaitu mengompol.

g. Subjek 3 (laki-laki) dengan umur 10 tahun sering menyaksikan tayangan misteri di televisi karena terbiasa dengan tontonan ibunya yang gemar dengan tayangan genre horror. Subjek terbiasa menyaksikan tayangan misteri di televisi sejak usia dini karena lingkungan sosial yang kurang mendukung subjek untuk berinteraksi dengan teman sebayanya.

h. Jenis tayangan misteri televisi yang telah disaksikan oleh subjek lebih beragam dibandingkan dengan subjek 1 dan 2, mulai dari yang kadar mistiknya ringan hingga yang berat. Demikian pula dengan frekuensi menontonnya lebih tinggi jika dibandingkan dengan subjek yang lain.

i. Reaksi subjek 3 saat sedang menyaksikan tayangan misteri di televisi tergantung dengan kadar mistik dari sebuah tayangan. Subjek merefleksikan rasa takutnya dengan cara menutup matanya, tangannya 
berkeringat dan dingin. Sedangkan reaksi panjangnya mengakibatkan subjek menjadi penakut, tidak mandiri, dan phobia terhadap binatang tertentu.

\subsection{Saran}

a. Seyogyanya stasiun televisi tidak menayangkan tayangan misteri pada jam tayang yang masih bisa disaksikan oleh anakanak.

b. Kepada rumah produksi $(\mathrm{PH})$ hendaknya tidak melebih-lebihkan efek visual dan audio dan mengutamakan muatan edukatif, sehingga dapat meminimalisir kesan mistik yang menyeramkan dan menegangkan.

c. Kepada pemerintah melalui KPI (Komisi Penyiaran Indonesia) agar mengawasi tayangan-tayangan yang ditampilkan televisi

d. Kepada orang tua agar mengawasi tontonan putera-puterinya yang masih berusia belia dan mendampingi mereka manakala terlanjur telah menontonnya agar dapat memberikan penjelasan yang berkaitan dengan tontonannya, dan tidak memperlihatkan reaksi takut karena ketakutan anak tergantung pengaruh lingkungan

\section{DAFTAR PUSTAKA}

Arta, Dewi, "Psikologi Anak Terhadap Film Horor", Online (http://zieshila.wordpress.com). Diakses 6 Juli 2010.

Alkaf, Yasir, "Rahasia Sulap Limbad" Online. (http://yasiralkaf.wordpress.com). Diakses 28 April 2009.

Damayanti, Euis. Pengaruh Tayangan Misteri Terhadap Anak. Online (http//www.pksjaksel.or.id939htm). diakses 6 Juli 2010.

Farida, "Menyikapi si Cengeng", Online (http://mommygadget.com). Diakses 23 Oktober 2009.

Gunarsah, Singgih, 2008, Dasar dan Teori Perkembangan Anak, (Cet.9), Jakarta: BPK Gunung Mulia.

Gunartih, Winda, Lilis Suryani dan Azizh Muis, 2008, Metode Pengembangan Perilaku dan Kemampuan Dasar Anak Usia Dini, Jakarta: UnivrsitasTerbuka.

Muhammad, Najamuddin, "Mewaspadai Efek Negatif PPeran Televisi", (Opini), Kompas, 4 Mei 2008.
Poerbabagus, "Tayangan Misteri di Televisi Tontonan or Tuntunan", Online. (http://poerbabagus.wordpress.com).

Diakses 29 Oktober 2009

Redaksi, "Kasus AnakBunuh diri Lihat Tayangan Master

Limbad,"Online (www.Oktavita.com). Diakses 19 Desember 2009

Surbakti, Awas Tayangan Televisi: Tayangan Misteri dan Kekerasan mengancam Anak Anda : Jakarta: Alex Media Komputindo. 